\title{
Robust syntaxin-4 immunoreactivity in mammalian horizontal cell processes
}

\author{
ARLENE A. HIRANO,${ }^{1,4}$ JOHANN HELMUT BRANDSTÄTTER,${ }^{5-6}$ ALEJANDRO VILA, ${ }^{1}$ \\ AND NICHOLAS C. BRECHA ${ }^{1-4}$ \\ ${ }^{1}$ Departments of Neurobiology \& Medicine, Geffen School of Medicine at UCLA, Los Angeles, California \\ ${ }^{2}$ Jules Stein Eye Institute, Geffen School of Medicine at UCLA, Los Angeles, California \\ ${ }^{3}$ CURE Digestive Diseases Research Center, Geffen School of Medicine at UCLA, Los Angeles, California \\ ${ }^{4}$ VAGLAHS, Los Angeles, California \\ ${ }^{5}$ Institute for Biology, Department of Animal Physiology, University of Erlangen-Nuernberg, Erlangen, Germany \\ ${ }^{6}$ Department of Neuroanatomy, Max Planck Institute for Brain Research, Frankfurt am Main, Germany
}

(ReCEIVEd January 19, 2007; ACCEPTED March 12, 2007)

\begin{abstract}
Horizontal cells mediate inhibitory feed-forward and feedback communication in the outer retina; however, mechanisms that underlie transmitter release from mammalian horizontal cells are poorly understood. Toward determining whether the molecular machinery for exocytosis is present in horizontal cells, we investigated the localization of syntaxin-4, a SNARE protein involved in targeting vesicles to the plasma membrane, in mouse, rat, and rabbit retinae using immunocytochemistry. We report robust expression of syntaxin-4 in the outer plexiform layer of all three species. Syntaxin-4 occurred in processes and tips of horizontal cells, with regularly spaced, thicker sandwich-like structures along the processes. Double labeling with syntaxin- 4 and calbindin antibodies, a horizontal cell marker, demonstrated syntaxin-4 localization to horizontal cell processes; whereas, double labeling with PKC antibodies, a rod bipolar cell (RBC) marker, showed a lack of co-localization, with syntaxin-4 immunolabeling occurring just distal to RBC dendritic tips. Syntaxin-4 immunolabeling occurred within VGLUT-1-immunoreactive photoreceptor terminals and underneath synaptic ribbons, labeled by CtBP2/RIBEYE antibodies, consistent with localization in invaginating horizontal cell tips at photoreceptor triad synapses. Vertical sections of retina immunostained for syntaxin-4 and peanut agglutinin (PNA) established that the prominent patches of syntaxin- 4 immunoreactivity were adjacent to the base of cone pedicles. Horizontal sections through the OPL indicate a one-to-one co-localization of syntaxin-4 densities at likely all cone pedicles, with syntaxin-4 immunoreactivity interdigitating with PNA labeling. Pre-embedding immuno-electron microscopy confirmed the subcellular localization of syntaxin-4 labeling to lateral elements at both rod and cone triad synapses. Finally, co-localization with SNAP-25, a possible binding partner of syntaxin-4, indicated co-expression of these SNARE proteins in the same subcellular compartment of the horizontal cell. Taken together, the strong expression of these two SNARE proteins in the processes and endings of horizontal cells at rod and cone terminals suggests that horizontal cell axons and dendrites are likely sites of exocytotic activity.
\end{abstract}

Keywords: SNARE complex, Exocytosis, Vesicular release

\section{Introduction}

The photoreceptor triad is a synaptic complex composed of a photoreceptor terminal, bipolar cell dendrite(s) and horizontal cell endings and forms the initial site of information transfer in the visual system. The photoreceptor presynaptic terminal is highly specialized, consisting of a synaptic ribbon, a large number of synaptic vesicles and a unique set of ribbon, and vesicular and synaptic proteins that mediate a graded release of glutamate.

Address correspondence and reprint requests to: Arlene A. Hirano, Ph.D., Geffen School of Medicine at UCLA, Dept. of Neurobiology, 10833 Le Conte Ave., Box 951763, Los Angeles, CA 90095. E-mail: ahirano@mednet.ucla.edu
Structurally, the triad is characterized by an invaginating ONbipolar cell dendrite(s) that is flanked by two horizontal cell endings. Outside the invagination, OFF-bipolar cell dendrites form basal contacts primarily at cone terminals but also at some rod spherules (Hack et al., 1999).

Horizontal cells are interneurons of the outer retina that project laterally within the OPL to contact multiple photoreceptor terminals. In most mammals, there are two types of horizontal cells: the A-type that is axonless with thick processes and the B-type that is axon-bearing and possesses finer processes. In rodents, there is only one morphological type, the B-type (Peichl \& GonzálezSoriano, 1994). The dendrites of both types of horizontal cells make contact with cone terminals, whereas the axon terminal processes of the B-type innervate those of rods (Peichl et al., 
1998). Although there is general agreement that horizontal cells mediate inhibitory feedback in part to generate receptive field surrounds in the outer retina and set the synaptic gain at the triad synapse (Peichl et al., 1998), the nature of how these cells signal to their postsynaptic partners is poorly understood in the mammalian retina.

The localization of a vesicular GABA transporter (VGAT) to horizontal cell processes in primate and rodent retinae (Haverkamp et al., 2000; Cueva et al., 2002) suggested that mammalian horizontal cells release transmitter in a vesicular manner. Indeed, horizontal cell endings in the synaptic triad contain small numbers of small, clear-core vesicles, though they lack conventionally defined presynaptic membrane specializations. GABA receptors have been localized to possible postsynaptic targets in the outer plexiform layer, such as bipolar cell dendrites (Vardi et al., 1998; Wässle et al., 1998) and cone photoreceptor terminals in cat, mouse, rat, and pig retinae (Vardi et al., 1992; Picaud et al., 1998; Pattnaik et al., 2000). Previously we have demonstrated the cellular and subcellular localization of vesicular release proteins, syntaxin1a, complexin-I/II, and synapsin I to horizontal cell processes in the triad synapse of rod and cone photoreceptors (Hirano et al., $2005 a$ ), suggesting that the molecular machinery for exocytosis is present. This vesicular mechanism differs from a previously established GABA plasmalemmal transporter mechanism described for non-mammalian horizontal cells (Schwartz, 2002).

Syntaxins are a family of membrane-associated proteins (Bennett et al., 1993) that bind to synaptosome associated protein of 25 $\mathrm{kD}$ (SNAP-25) and synaptobrevin/VAMP (vesicle associated membrane protein) to form the core SNARE (soluble N-ethylmaleimidesensitive factor attachment protein receptor) complex (Rizo \& Südhof, 2002; Jahn \& Scheller, 2006) that drives membrane fusion of vesicles. Syntaxins confer target membrane specificity through the use of various isoforms, with syntaxins 1-4 targeting to the plasma membrane (Chen \& Scheller, 2001). Sherry et al. (2006) reported the unique distributions of these syntaxin isoforms in the mouse retina: syntaxin-1 and -2 in amacrine cells and their processes but in a non-overlapping fashion; syntaxin-3 in ribbon synapses of photoreceptors and bipolar cells; and syntaxin-4 to horizontal cells. To further explore the possible mechanism of vesicular release of transmitter from mammalian horizontal cells, we studied the cellular and subcellular localization of syntaxin- 4 in several mammalian species. We find that syntaxin- 4 is prominently expressed in processes and tips of horizontal cells in mouse, rat, and rabbit retinae in the same cellular compartment as SNAP-25 and confirm the subcellular localization to horizontal cell processes at photoreceptor terminals in the mouse retina. Some of the results have been presented in abstract form (Hirano et al., 2006).

\section{Materials and methods}

Adult C57BL/6 mice (20-30 g), Sprague-Dawley rats (250-300 g) and New Zealand White rabbits (3-4 kg) of either sex were used for these studies. All experiments were performed in accordance with the guidelines for the welfare of experimental animals issued by the United States Public Health Service Policy on Human Care and Use of Laboratory Animals (2002), the University of California, Los Angeles (UCLA) Animal Research Committee, and the Max Planck Society and the Federal Government of Germany. Following deep anesthesia with $1 \%$ to $3 \%$ isofluorane (rodents; IsoFlo, Abbott Laboratories, Abbott Park, IL) or ketamine-xylazine (30 $\mathrm{mg} / \mathrm{kg}$ ketamine intraperitoneally (i.p.), Ketajet, Phoenix Scientific, Inc. (St. Joseph, MO); 3 mg/kg xylazine i.p., Xyla-jet, Phoe- nix Scientific, Inc.) followed by pentobarbital (rabbits; 100-200 $\mathrm{mg} / \mathrm{kg}$ intravenously, Nembutal, Abbott Laboratories), the eyes were enucleated, and the anterior chamber and lens were removed. The eyecups were immersion-fixed in $4 \%(\mathrm{w} / \mathrm{v})$ paraformaldehyde (PFA) in $0.1 \mathrm{M}$ phosphate buffer $(\mathrm{PB}), \mathrm{pH} 7.4$, for $15-30 \mathrm{~min}$ or in $2 \%$ PLP (2\% (w/v) PFA, $1.37 \%$ (w/v) D, L-lysine, $0.214 \%$ (w/v) sodium periodate $\left.\left(\mathrm{NaIO}_{4}\right)\right)$ for $20 \mathrm{~min}$, cryoprotected in graded $(10 \%$ to $30 \%$ ) or $30 \%$ sucrose, and sectioned vertically at $12-14 \mu \mathrm{m}$ on a cryostat onto gelatin-coated slides. For sliding microtome sections, the retina was isolated, flattened, and cut parallel to the vitreal surface at $30-\mu \mathrm{m}$ thickness to obtain horizontal sections of retina. Free-floating sections were stored in $0.1 \mathrm{M} \mathrm{PB}$ at $4^{\circ} \mathrm{C}$ until antibody staining and processed similarly to vertical sections, except that free-floating sections were incubated in primary antibody for several days at $4^{\circ} \mathrm{C}$ with gentle agitation.

\section{Antibodies}

Primary antibodies and their dilutions were as follows: rabbit polyclonal antibodies against syntaxin-4 (1:100-1:1000/0.3-3 $\mu \mathrm{g} /$ $\mathrm{mL}$, typically $1: 400 / 0.75 \mu \mathrm{g} / \mathrm{mL}$, Chemicon, Temecula, CA, AB5330), mouse monoclonal antibody against Calbindin-28K (1:2000-1:5000, Sigma (St. Louis, MO), C9848, clone CB-955), mouse monoclonal antibody against protein kinase $\mathrm{C} \alpha(\mathrm{PKC} \alpha$, 1:1000, Biodesign, Saco, ME, K01107M, clone MC5), mouse monoclonal antibody against $\mathrm{C}$-terminal binding protein-2/RIBEYE (CtBP2/RIBEYE, 1:200, BD Transduction Laboratories, San Jose, CA), mouse monoclonal antibody to SNAP-25 (1:20,000, Synaptic Systems, Göttingen, Germany, 111011 ), and a guinea pig polyclonal antibodies to vesicular glutamate transporter 1 (VGLUT1, 1:20,000, Chemicon, AB5905). The antibodies used in this study are listed in Table 1. Chemicals used were purchased from Sigma unless otherwise noted.

\section{Controls for the antibodies}

Preadsorption of the syntaxin 4 antibody with the cognate peptide blocked all specific immunoreactivity (Fig. 1D). Western blot analysis using the same antibody on mouse retina and brain tissue (Sherry et al., 2006) or rabbit brain tissue (Gouraud et al., 2002) recognized a single band of $\mathrm{M}_{\mathrm{r}}$ of $36 \mathrm{kD}$. In addition, Western blot analysis using tissue from heterozygous syntaxin- 4 knockout mice demonstrated an approximately $50 \%$ reduction in the intensity of the syntaxin- 4 band (Spurlin \& Thurmond, 2006); whereas, transgenic mice that overexpressed syntaxin-4 showed increased syntaxin-4 protein (Spurlin et al., 2004). Numerous antibodies to calbindin D-28K have been used to identify horizontal cells in mammalian retinae (Röhrenbeck et al., 1987; Massey \& Mills, 1996; Haverkamp \& Wässle, 2000; Hirano et al., 2005a). Antibodies to PKC $\alpha$ have been used as neurochemical markers of rod bipolar cells in various species (Negishi et al., 1988; Greferath et al., 1990; Haverkamp \& Wässle, 2000). A guinea pig polyclonal antibody against VGLUT1 (Chemicon AB5905) was used to identify photoreceptor axon terminals (Johnson et al., 2003; Sherry et al., 2003; Fyk-Kolodziej et al., 2004). The staining pattern obtained with the guinea pig antibody corresponds to that described for other VGLUT1 antisera (Todd et al., 2003), and preadsorption of the VGLUT1 antiserum with the antigenic peptide results in a block of specific immunostaining (Fyk-Kolodziej et al., 2004). As an additional negative control, the omission of the primary antibodies in the single or double labeling studies confirmed the elimination of specific labeling for all antibodies used. 
Table 1. List of antibodies applied in the current study

\begin{tabular}{|c|c|c|c|c|}
\hline Antigen & Antiserum & Immunogen & Source & Working dilution \\
\hline Calbindin D-28kD & Mouse, clone CB-955 & purified bovine kidney calbindin D-28k & Sigma, St. Louis, MO, C9848 & $1: 2,500-1: 5,000$ \\
\hline $\mathrm{CtBP} 2$ & Mouse & C-terminal a.a. $361-445 \mathrm{~ms} \mathrm{CtBP2}$ & $\begin{array}{l}\text { BD Transduction Laboratories, } \\
\text { San Jose, CA, } 612044\end{array}$ & $1: 200$ \\
\hline $\mathrm{PKC} \alpha$ & Mouse, clone MC5 & Protein Kinase $\mathrm{C} \alpha$ & Biodesign, Saco, ME, K01107M & $1: 1000$ \\
\hline SNAP-25 & Mouse & N-terminal a.a. $20-40$ rat SNAP-25 & $\begin{array}{l}\text { Synaptic Systems, Göttingen, } \\
\text { Germany, } 111011\end{array}$ & $1: 20,000$ \\
\hline Syntaxin-4 & Rabbit & N-terminal a.a. $2-23 \mathrm{rat} / \mathrm{ms}$ syx-4 & Chemicon, Temecula, CA, AB5330 & $1: 400$ \\
\hline Syntaxin-4 & Rabbit & $\mathrm{N}$-terminal a.a. $2-23 \mathrm{rat} / \mathrm{ms}$ syx-4 & Calbiochem, La Jolla, CA, 574788 & $1: 300-1: 3000$ \\
\hline Syntaxin-4 & Rabbit & N-terminal a.a. $2-23 \mathrm{rat} / \mathrm{ms}$ syx -4 & Sigma, St. Louis, MO, S9924 & $1: 300-1: 3000$ \\
\hline VGLUT-1 & Guinea pig & Synthetic peptide from rat VGLUT1 & Chemicon, AB5905 & $1: 20,000$ \\
\hline
\end{tabular}

\section{Light microscopy}

Immunostaining was performed using the indirect fluorescence method (Grünert \& Wässle, 1993; Sassoé-Pognetto et al., 1994). In brief, retinal sections were incubated in primary antibody diluted in 3\% normal goat serum (Invitrogen, Carlsbad, CA), $1 \%$ bovine serum albumin, $0.5 \%$ Triton $\mathrm{X}-100,0.05 \%$ sodium azide $\left(\mathrm{NaN}_{3}\right)$, $0.1 \mathrm{M} \mathrm{PB}$, for 12 to $16 \mathrm{~h}$ at room temperature. The specific immunolabeling was visualized using Alexa Fluor 488-, 568- or 594-conjugated anti-rabbit, mouse, or guinea pig IgG secondary antibodies (Molecular Probes, Carlsbad, CA) at 1:500 dilutions for $1 \mathrm{~h}$ at room temperature. For labeling of cone photoreceptors, sections were incubated in fluorescein isothiocyanate (FITC)conjugated PNA (FITC-PNA, 1:400, Vector Labs, Burlingame, CA) for $1 \mathrm{~h}$, after primary antibody labeling.

The immunostaining was examined on a Zeiss Laser Scanning Microscope 510 Meta (LSM 510, Carl Zeiss, Inc., Thornwood, NY, USA) with Zeiss $40 \times 1.3$ NA Plan-NEOFLUAR oil and C-Apochromat $40 \times 1.2$ NA corrected water objectives. Typically, stacks of 3 images ( $n=3-7,2048 \times 2048$ pixels) of $1.0-\mu$ m thickness $(0.9-\mu \mathrm{m}$ green channel, $1.0-1.2-\mu \mathrm{m}$ red channel) were collected, separated by z-steps of $0.3 \mu \mathrm{m}$ (range $=0.3-0.5 \mu \mathrm{m}$ ). Exceptions to this are noted in the figure legends. Confocal images were analyzed using the Zeiss LSM 510 proprietary software (version 3.2). Intensity levels and brightness/contrast were adjusted in Adobe Photoshop CS v.8.0 (Adobe Systems, San Jose, CA).

\section{Pre-embedding immunoelectron microscopy}

Immunolabeling was performed by using pre-embedding immunoelectron microscopy techniques, as previously described (Brandstätter et al., 2004). In brief, the eyecups were fixed for $50 \mathrm{~min}$ in $4 \%(\mathrm{w} / \mathrm{v})$ PFA, the retinae were removed, cryoprotected in graded sucrose, and frozen and thawed three times to improve antibody penetration. Vibratome sections were cut at $50 \mu \mathrm{m}$-thickness into cold PBS, pH 7.4. The primary antibody against syntaxin-4 was used at 1:1000 and diluted in the same media used for light microscopy, except that Triton X-100 was omitted, and the sections were incubated for four days at $4^{\circ} \mathrm{C}$. Immunolabeling was visualized by the $\mathrm{ABC}$ method (Vectastain Elite $\mathrm{ABC}$ kit, Vector Laboratories, Burlingame, $\mathrm{CA}$ ) using 3,3'-diaminobenzidine (DAB) as substrate. The DAB reaction product was silver intensified and gold toned, and the tissue was flat embedded in Epon 812 (Serva, Heidelberg, Germany). Ultrathin sections were cut and then contrasted with uranyl acetate and lead citrate. The ultrathin sections were examined and photographed with a Zeiss EM10 electron microscope (Zeiss, Oberkochen, Germany) and a GATAN BioScan digital camera $(1024 \times 1024$ pixel; GATAN, Munich, Germany) in combination with the software program DIGITAL MICROGRAPH 3.1 (GATAN).

\section{Results}

Syntaxin-4 immunolabeling occurs largely in the outer plexiform layer of mouse, rat and rabbit retinae

Syntaxin-4 antibodies were applied to vertical cryostat sections of mouse, rat, and rabbit retinae. The principal immunolabeling in the retina occurred in the outer plexiform layer (OPL) in all three species (Fig. 1). There was strong globular immunoreactivity at the end of labeled stalks of putative horizontal cell processes. Deeper in the OPL, there were prominent densities of syntaxin-4 immunoreactivity, spaced at regular intervals along the OPL (arrows). In mouse retina, these syntaxin-4 structures resembled sandwiches, reminiscent of glutamate receptor labeling at cone pedicle bottoms (Haverkamp et al., 2000). In mouse and rat retinae, but not in rabbit retina, there were also fine processes in the inner plexiform layer (IPL) and very sparse amacrine cell somata labeled in the proximal inner nuclear layer (INL, data not shown). Syntaxin-4 immunolabeling in the inner retina will not be further characterized in this report.

\section{Syntaxin-4 immunoreactivity localizes to horizontal cells}

To confirm that syntaxin-4 immunoreactivity corresponded to processes of horizontal cells, double label experiments with antibodies to syntaxin-4 and calbindin, a horizontal cell marker (Röhrenbeck et al., 1987; Massey \& Mills, 1996; Haverkamp \& Wässle, 2000; Hirano et al., 2005a) were conducted. Similar results were obtained in all three species examined and the data from mouse retina are shown (Fig. 2). Calbindin antibodies labeled the horizontal cells in their entirety: soma, processes, and endings that invaginate photoreceptor terminals (Fig. 2A). Syntaxin-4 antibodies labeled the horizontal cell endings and sandwiches, as well as faint outlines of horizontal cell bodies (Fig. 2B). In the merged image, the syntaxin-4 immunoreactivity (Fig. 2C) colocalized precisely with the processes and endings of horizontal cells.

\section{Syntaxin-4 does not localize to rod bipolar cell dendrites}

To exclude the possibility that some of the syntaxin-4 labeled endings in the OPL correspond to the dendrites of ON bipolar 

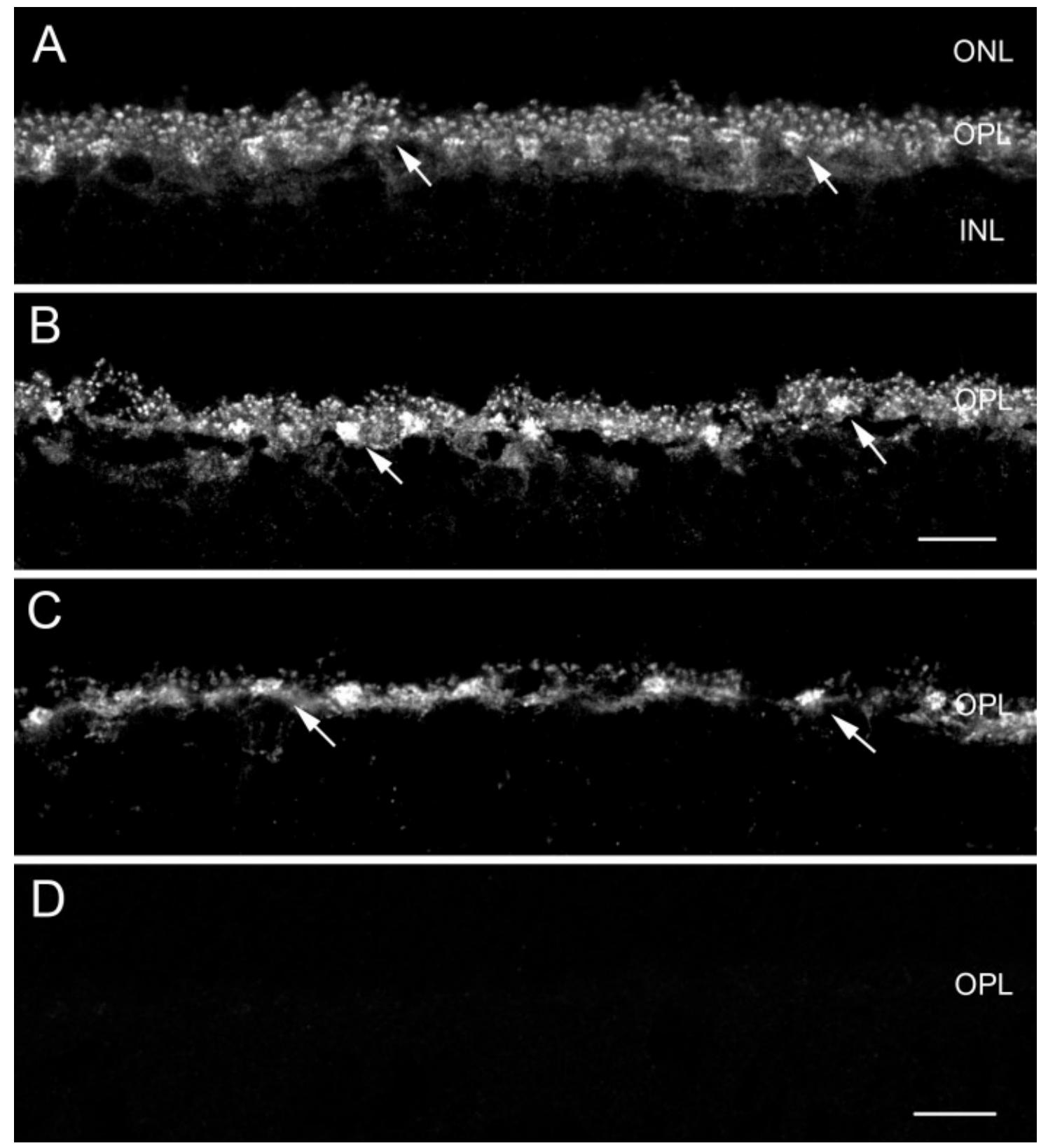

Fig. 1. Syntaxin-4 immunolabeling in the outer plexiform layer of mouse, rat and rabbit retinae. Localization of syntaxin-4 immunoreactivity in vertical sections of $(\mathbf{A})$ mouse, $(\mathbf{B})$ rat, and $(\mathbf{C})$ rabbit outer retina. Note the prominent immunoreactivity in the outer plexiform layer of all three species. Arrows point toward thickenings or sandwiches of syntaxin-4 immunolabeling. (D) Pre-adsorption of the antibody with the antigenic peptide abolishes specific labeling in rabbit retina. (A) Projection of 3 images, (B) Projection of 5 images, $\mathrm{z}=0.46 \mu \mathrm{m}$, (C) Projection of 3 images. ONL, outer nuclear layer; OPL, outer plexiform layer; INL, inner nuclear layer. Scale bars, $10 \mu \mathrm{m}$ (A to B in B, C to D in D).

cells, which also invaginate photoreceptor terminals, retinal sections were double labeled with antibodies to syntaxin-4 (Fig. 3A) and protein kinase $\mathrm{C} \alpha$ (PKC $\alpha$, Fig. 3B), a marker for rod bipolar cells (RBC, Negishi et al., 1988; Greferath et al., 1990; Haverkamp \& Wässle, 2000). Similar results were obtained in all three species examined and the data from mouse retina are shown. The syntaxin- 4 immunoreactivity in the OPL occurs just distal or adjacent to the dendrites of the RBCs (Fig. 3C), suggesting that the syntaxin-4containing tips were only those of the horizontal cells and that rod bipolar cell dendrites do not contain syntaxin-4. Note in the three-fold magnified insets of the OPL the syntaxin-4 immunoreactivity is distinct in shape adjacent to the thin process-like PKC-labeled bipolar cell dendrite.

\section{Syntaxin-4 is present within the triad synapse}

To demonstrate that the syntaxin- 4 immunoreactivity occurs in the horizontal cell processes within the triad synapse of photoreceptor terminals, double label experiments with syntaxin-4 and two markers of photoreceptor terminals, the VGLUT1 (Johnson et al., 2003; 

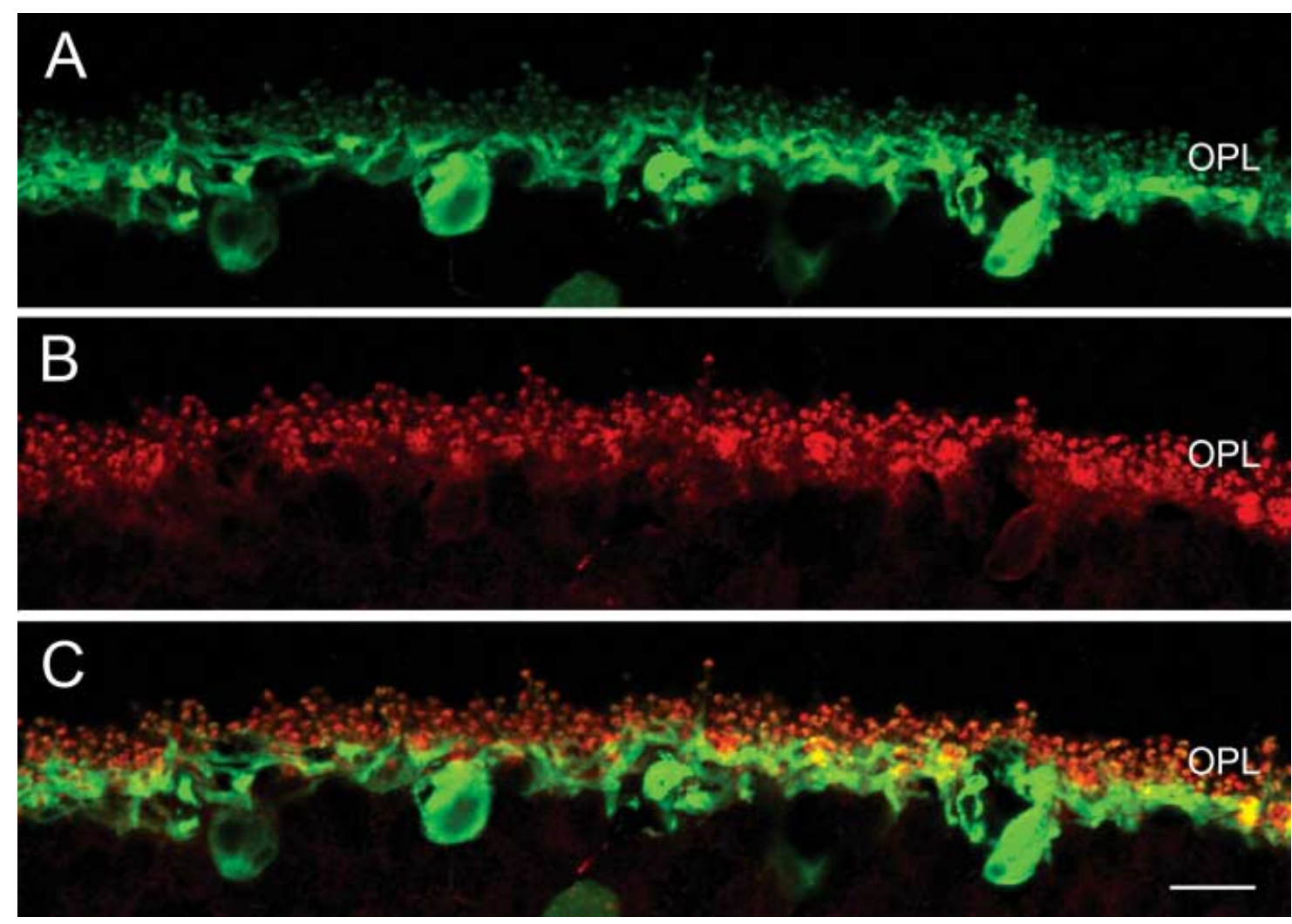

Fig. 2. Syntaxin-4 immunoreactivity localizes to horizontal cells. Double label experiments with antibodies to syntaxin-4 (red) and calbindin (green), a marker for horizontal cells, in a vertical section of mouse outer retina. (A) Calbindin antibodies label the somata and processes of horizontal cells. (B) Syntaxin-4 immunolabeling in the OPL. (C) Merged image showing co-localization of syntaxin-4 in horizontal cell processes and tips. (A to C) Projection of 7 images. OPL, outer plexiform layer. Scale bar, $10 \mu \mathrm{m}$ (A to C in C).

Sherry et al., 2003; Fyk-Kolodziej et al., 2004) and CtBP2/ RIBEYE, a component of the synaptic ribbons (Schmitz et al., 2000; Piatigorsky, 2001) were performed. Similar results were obtained in all three species examined and the data from mouse retina are shown (Fig. 4). VGLUT1 immunolabeling of glutamatecontaining synaptic vesicles shows donut-like labeling of photoreceptor terminals, with a notch or drop in intensity in the center, likely where the invaginating processes of the second-order neurons insert (Figs. 4A-4C). In the insets (Figs. 4C and 4F), showing a two-fold magnification of the marked box in the OPL, double labeling with VGLUT1 and syntaxin- 4 antibodies produces a central red spot (syntaxin-4) surrounded by the green VGLUT1 immunoreactivity (Figs. 4A to $4 \mathrm{C}$ insets). The synaptic ribbons, labeled with CtBP2 antibodies in red, are presumed to be at or very close to the sites of glutamate release from the photoreceptor synapse (tom Dieck et al., 2005; tom Dieck \& Brandstätter, 2006). The syntaxin-4 immunoreactivity appears to be capped by the CtBP2/RIBEYE-containing synaptic ribbons (Figs. 4D-4F \& insets), consistent with the conclusion that syntaxin-4 labeled endings correspond to the tips of the horizontal cells at photoreceptor ribbon synapses.

Syntaxin-4 sandwiches in horizontal cell processes are postsynaptic to cone pedicles

Whereas the markers for the glutamatergic synaptic vesicles (VGLUT1) and synaptic ribbons (CtBP2) label both rod and cone photoreceptor terminals, the base of cone pedicles in mouse retina can be labeled selectively with FITC-PNA (Blanks \& Johnson, 1984). Fig. 5 shows a vertical section of mouse retina labeled with syntaxin-4 antibodies (red) and FITC-PNA (green), with the outer segments and the base of cone pedicles strongly labeled by PNA (Fig. 5A). The syntaxin- 4 densities can be observed at regular intervals along the OPL (Fig. 5B). The merged image showed that the syntaxin- 4 densities coincided with the base of cone pedicles (Fig. 5C). In Figs. 5D to 5F, horizontal sections of rabbit OPL are shown. The FITC-PNA-labeled cone pedicle bottoms (green) and the hotspots of syntaxin-4 immunoreactivity within horizontal cell processes (red) can be observed in the top and middle panels, respectively. The merged image in Fig. $5 \mathrm{~F}$ demonstrated that the labels occur in the same patches and that the syntaxin- 4 endings appear to interdigitate between the gaps in the cone pedicle bottoms. This observation is consistent with the cellular localization of syntaxin- 4 to horizontal cell endings at cone photoreceptors, and not in the cone pedicles themselves.

\section{Syntaxin-4 locates ultrastructurally to lateral elements at the photoreceptor triad synapse}

Pre-embedding immuno-electron microscopy on mouse retina confirmed strong syntaxin-4 labeling in the lateral elements arising from horizontal cells within rod (Figs. 6A to 6B) and cone terminals (Figs. 6C to 6D), with no labeling in the photoreceptor terminal and the invaginating bipolar cell process at triad synapses. 

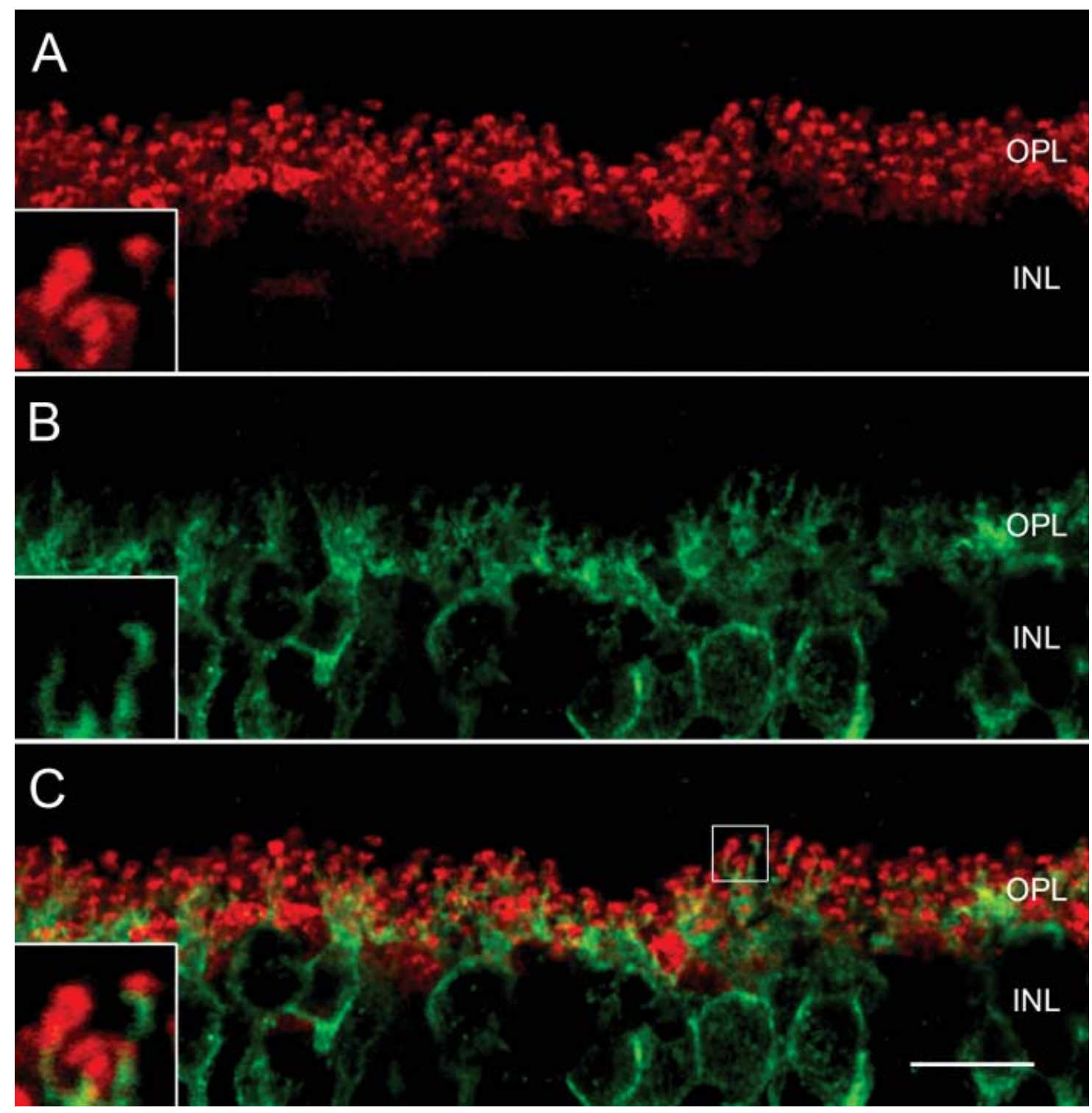

Fig. 3. Syntaxin- 4 does not localize to rod bipolar cell (RBC) dendrites. Double label for syntaxin- 4 and PKC $\alpha$ in a vertical section of mouse retina. (A) Syntaxin-4 (red) immunolabeling in the OPL. (B) PKC $\alpha$ immunolabeling (green) of RBCs. (C) Merged image shows syntaxin-4 immunoreactivity in puncta just distal or adjacent to the dendrites of the RBCs, indicating a lack of colocalization. The insets show a three-fold magnification of the marked box in the OPL. (A to C) Projection of 4 images. OPL, outer plexiform layer; IPL, inner plexiform layer. Scale bar, $10 \mu \mathrm{m}$ (A to C in C).

Sometimes only one (Figs. 6A and 6C) and sometimes both (Figs. 6B and 6D) lateral elements at the triad synapse were labeled. This labeling pattern is commonly observed in preembedding electron microscopy and is likely because of technical reasons regarding antibody penetration into the tissue and the limits imposed by the determination of labeling specificity. There is strong syntaxin- 4 immunolabeling underneath cone pedicles in presumed horizontal cell processes, consistent with the observations made at the light microscopic level. However, it is not clear whether syntaxin-4 immunolabeling occurs at desmosome-like junctions between horizontal cell processes (Haverkamp et al., 2000) as strong immunolabeling obscured the junctions, identified by their electron-dense appearance. Weaker immunolabeling that permitted identification of desmosome-like junctions did not yield clear syntaxin-4 immunoreactivity at these sites; however, it is difficult to discriminate whether this observation arose from the actual lack of the protein or a technical problem of understaining.

\section{Syntaxin-4 and SNAP-25 immunoreactivities co-localize in horizontal cell processes and endings}

The target-SNAREs, syntaxin and SNAP-25, and a vesicleSNARE, synaptobrevin/VAMP, combine to form the core SNARE complex, and the formation of this complex drives membrane fusion of synaptic vesicles during exocytosis (Südhof, 2004; Wang $\&$ Tang, 2006). Thus, it was of interest to see whether the syntaxin- 4 and SNAP-25 co-localized in the same subcellular compartment. The double labeling experiment in mouse retina is shown (Fig. 7), 

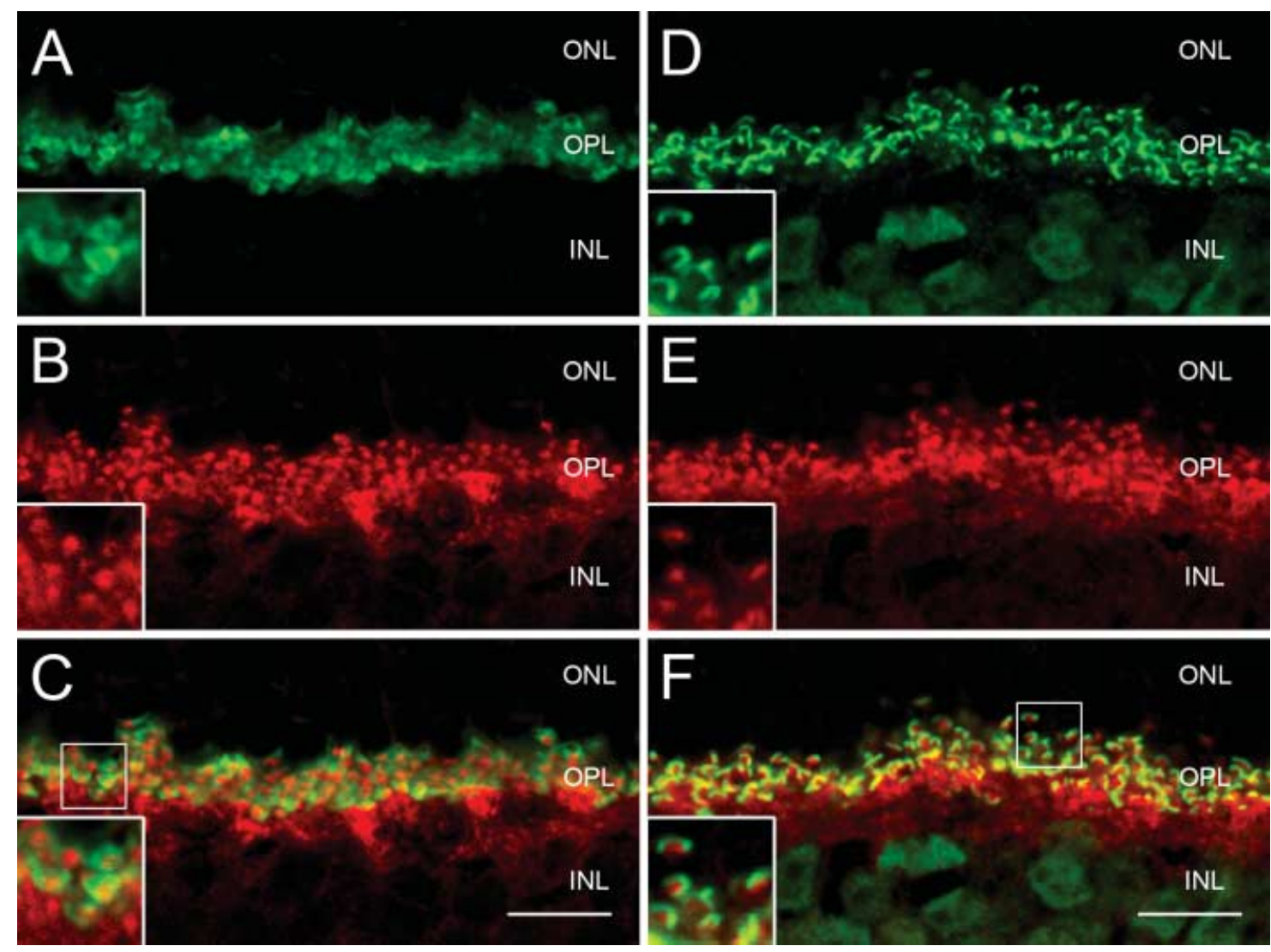

Fig. 4. Syntaxin-4 is present within the triad synapse. Double label experiments with antibodies to syntaxin-4 (red, B, E) and photoreceptor terminal markers, VGLUT1 (green, A) or CtBP2/RIBEYE (green, D). (C) Merged image shows syntaxin-4 immunoreactivity within photoreceptor terminals, outlined by VGLUT1 immunoreactivity. (F) Merged image shows syntaxin-4 immunoreactivity is capped by synaptic ribbons, labeled by CtBP2/RIBEYE antibodies. Insets show a two-fold magnification of the marked box in the OPL. (A to C) Projection of 5 images, (D to F) Projection of 3 images. ONL, outer nuclear layer; OPL, outer plexiform layer; INL, inner nuclear layer. Scale bars, $10 \mu \mathrm{m}$ (A to C in C, B to E in E).

and similar results were obtained in rat and rabbit (data not shown). Previously, we have shown that all SNAP-25 antibodies tested strongly label the processes and endings of retinal horizontal cells in all three species (Hirano et al., 2005b); in addition, various subsets of SNAP-25 antibodies produced different patterns of staining and stained a greater proportion of the retina. The double label experiments with antibodies to syntaxin-4 (Fig. 7B) and SNAP-25 (Fig. 7A), that is relatively specific for horizontal cell processes, demonstrated that the two proteins co-localize in the processes and endings of horizontal cells (Fig. 7C), with syntaxin-4 immunoreactivity prominent in the tips of the horizontal cell endings.

\section{Discussion}

Prominent syntaxin-4 immunoreactivity occurs in horizontal cell processes and endings in the outer retina and is enriched at the synapses with rods and cones in mouse, rat, and rabbit retinae. These studies extend earlier findings of Sherry et al. (2006) in mouse retina and also show syntaxin-4 immunoreactivity in rat and rabbit, suggesting that it is likely to be a general mammalian feature. The concentration of syntaxin- 4 at processes and tips adjacent to photoreceptor synapses suggests a role in synaptic transmission. The co-localization of syntaxin-4 with SNAP-
25, a binding partner in the SNARE complex, in horizontal cell processes and tips places them in the same subcellular compartment where they likely interact during vesicular fusion. Syntaxin-4 belongs to a subset of syntaxins that target vesicles to the plasma membrane (Chen \& Scheller, 2001; Teng et al., 2001; Salaün et al., 2004). Taken together, the strong expression of these two SNARE proteins in the processes and endings of horizontal cells at rod and cone terminals suggests that the horizontal cell axon and dendrites are likely sites of exocytotic activity.

\section{Pre- or postsynaptic function?}

The question arises as to what type of vesicle is trafficked to the plasma membrane via syntaxin-4 and the SNARE proteins that have been localized to the processes and endings of mammalian horizontal cells. Two possibilities are transmitter-filled vesicles or vesicles involved in postsynaptic insertion of a membrane protein at horizontal cell endings. The presence of clear-cored vesicles (Dowling \& Boycott, 1966; Dowling et al., 1966; Linberg \& Fisher, 1988; Spiwoks-Becker et al., 2001) in horizontal cell processes and endings in mammals indicate that the morphological basis for vesicular release of neurotransmitter exists. The localization of synaptic proteins, such as SNAP-25 (Hirano et al., 2005b), 

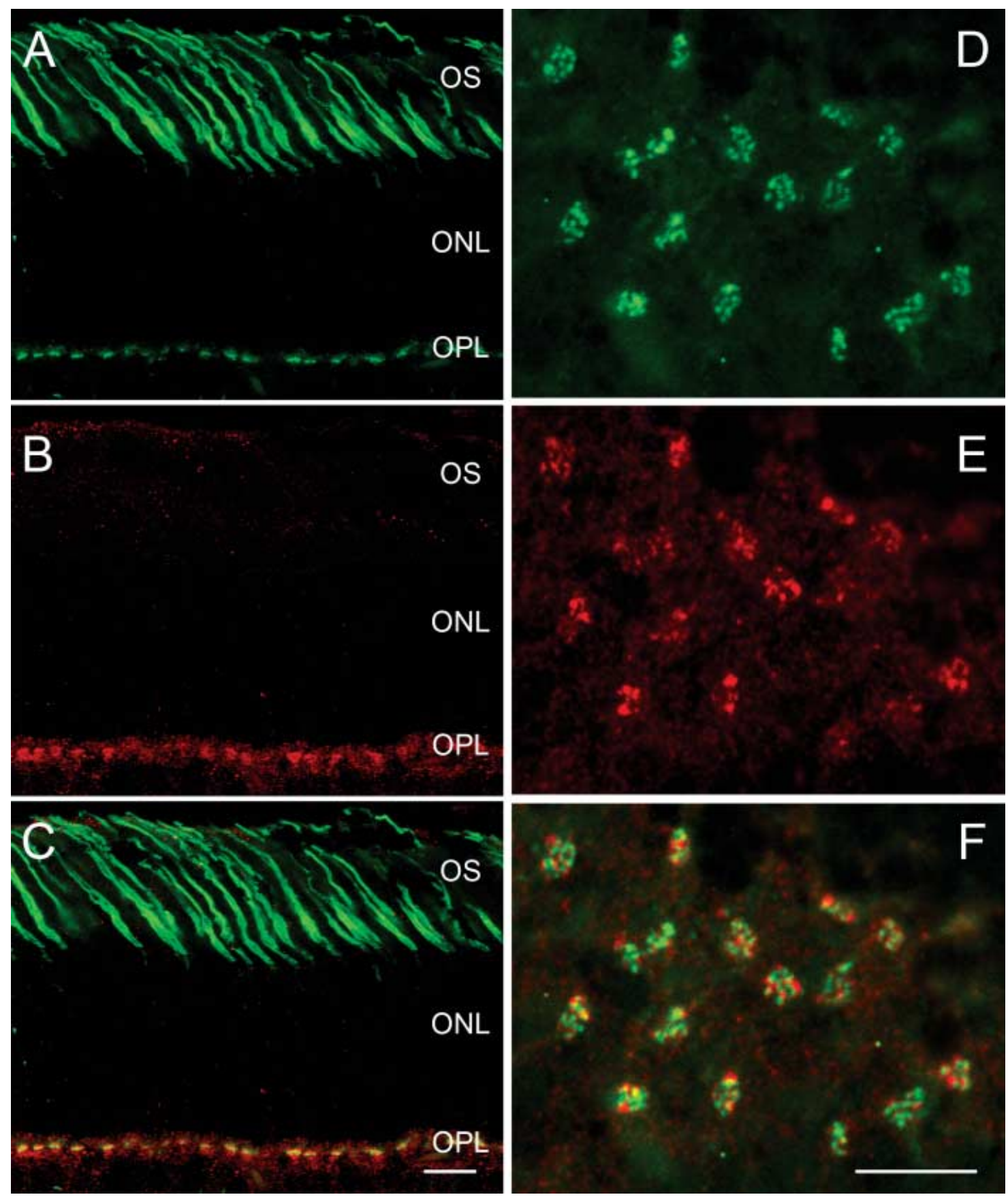

Fig. 5. Syntaxin-4 sandwiches in horizontal cell processes are coincident with cone pedicles. (A to $\mathbf{C})$ Vertical section of mouse outer retina double labeled with FITC-PNA (green, A) and syntaxin-4 (red, B) antibodies demonstrated syntaxin-4 densities occur adjacent to the base of cone pedicle (merge, C). (D to F) Horizontal section through the OPL of rabbit retina labeled with (D) FITC-PNA and for (E) syntaxin-4. (F) Note the association between the intense syntaxin-4 patches with the cone pedicles in the merged image and that the syntaxin- 4 processes interdigitate with the PNA-labeled base of cone pedicles, indicating that the syntaxin-4 occurs in the invaginating horizontal cell processes and not in the cone pedicle. (A to C) Projection of 3 images, $z=0.5 \mu \mathrm{m}$, (D to F) Projection of 3 images of $1.2 \mu \mathrm{m}$ thickness (red). OS, outer segments; ONL, outer nuclear layer; OPL, outer plexiform layer. Scale bars, $10 \mu \mathrm{m}$ (A to $\mathrm{C}$ in $\mathrm{C}, \mathrm{D}$ to $\mathrm{F}$ in $\mathrm{F}$ ).

syntaxin-1a, complexin-I/II, synapsin I (Hirano et al., 2005a) and syntaxin-4 (this report), and synaptic vesicle proteins, most prominently, VGAT (Haverkamp et al., 2000; Cueva et al., 2002; Jellali et al., 2002) to horizontal cell processes, provides a growing list of synaptic proteins suggestive of vesicular release of transmitter.
Furthermore, the presence of L- (Rivera et al., 2001; Schubert et al., 2006) and N-types of calcium currents (Schubert et al., 2006) in mammalian horizontal cells indicate that regulated or calcium-dependent release of transmitter from horizontal cells could occur. 

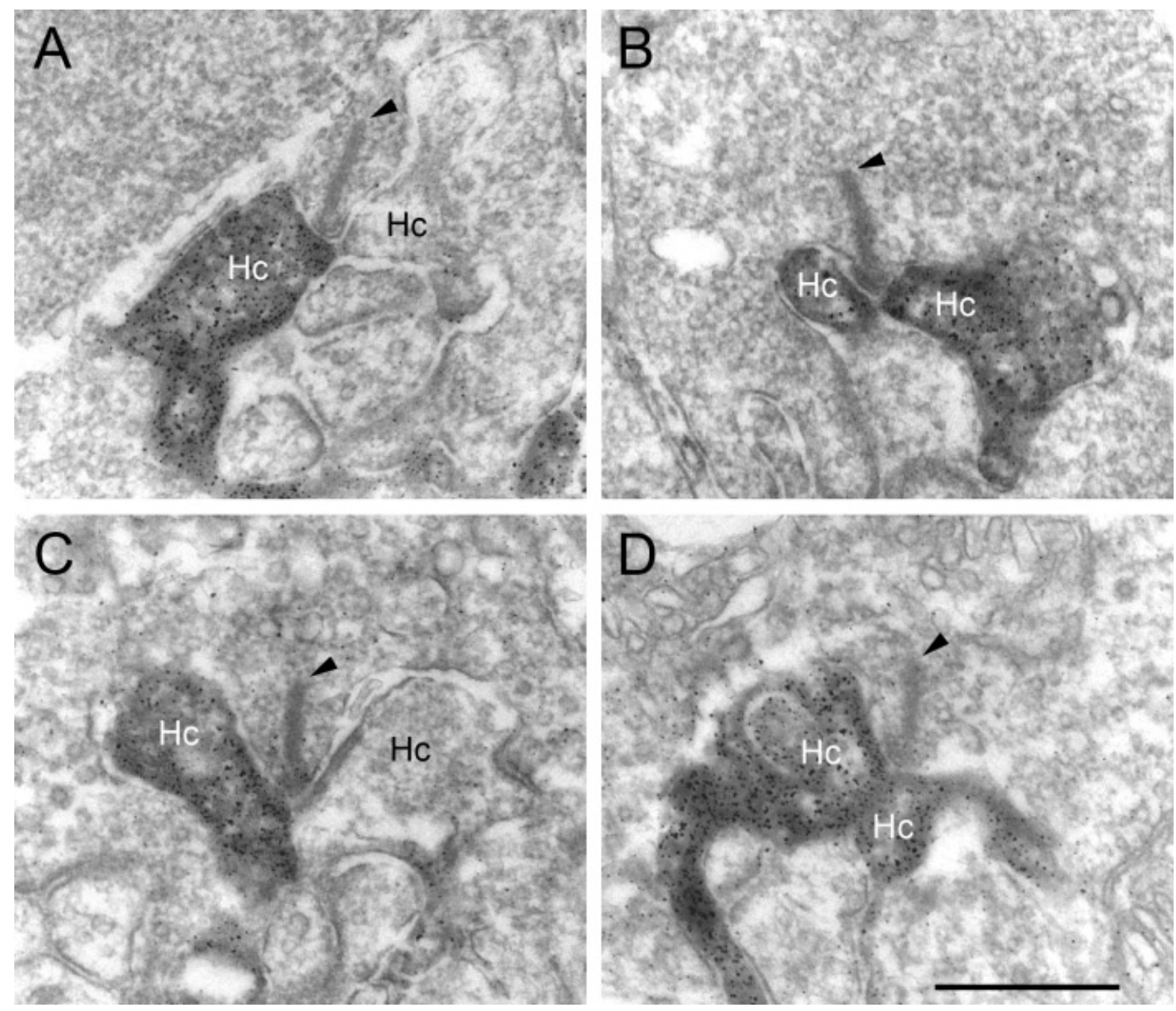

Fig. 6. Pre-embedding immuno-electron microscopy on mouse retina demonstrated subcellular localization of syntaxin-4 to the lateral elements within the triad synapse of both $\operatorname{rod}(\mathbf{A}, \mathbf{B})$ and cone $(\mathbf{C}, \mathbf{D})$ terminals. The dark granular DAB immunolabeling occurs in one (A, C) and sometimes both (B, D) lateral elements. Arrowheads point to the synaptic ribbons in the photoreceptor terminals. Hc, horizontal cell. Scale bar, $0.5 \mu \mathrm{m}$ (A to D in D).

\section{Role of syntaxin-4 in other tissues}

Whereas the functional role of syntaxin-4 in neurons remains undetermined, syntaxin- 4 has been shown in other cell types and organs to be involved in the regulated transport of proteins to the plasma membrane (Grusovin \& Macaulay, 2003; Noda \& Sasaki, 2005), targeting of vesicles to the basolateral plasma membranes of polarized cells (ter Beest et al., 2005), and in granule secretion (Logan et al., 2003; Stow et al., 2006). Examples of regulated transport of membrane proteins include the insulin-induced translocation of glucose transporter 4 to the plasma membrane of adipocytes (Olson et al., 1997), the insertion of aquaporin 2 in response to vasopressin in the renal cells (Gouraud et al., 2002), and the redistribution of neuronal glutamate transporters into and out of the plasma membrane as a mechanism of synaptic regulation (Fournier \& Robinson, 2006; Robinson, 2006). Madison et al. (1999) provide evidence that targeting of myelin vesicles to the plasma membrane in oligodendrocytes utilizes syntaxin-4. The participation of SNARE proteins implies that this transport to the plasma membrane is vesicular.

In several polarized cell types, syntaxin-4 localizes and targets proteins to the basolateral plasma membrane, whereas syntaxin-2 (Hansen et al., 1999) or syntaxin-3 (ter Beest et al., 2005) are found at the apical surface. With respect to neurons, "basolateral" corresponds to the dendritic compartment, whereas "apical" corresponds to axons (Peters et al., 1991). In B-type horizontal cells, syntaxin-4 appears to localize to and demarcate the processes and endings of horizontal cells in both dendrites (at cone terminals) and axon terminals (at rod terminals), suggesting a lack of compartmentalization to dendrites or axons per se.

Syntaxin-4 is involved also in different types of secretion from non-neural cells. For example, it has been shown to play a role in insulin secretion from pancreatic islet beta-cells (Spurlin et al., 2004; Spurlin \& Thurmond, 2006). Syntaxin-4 participates in granule release from cells in the immune system (Stow et al., 2006), such as crystalloid granules from eosinophils (Logan et al., 2003), several types of granules from neutrophils (Logan et al., 2003), degranulation of mast cells (Blank et al., 2001), and cytokine secretion from macrophages (Pagan et al., 2003). In platelets, syntaxin-4 mediates alpha-granule and lysosome secretion (Chen et al., 2000; Lemons et al., 2000). By analogy, the presence of syntaxin-4 in horizontal cells could indicate that the kinetics of vesicular release may reflect a 

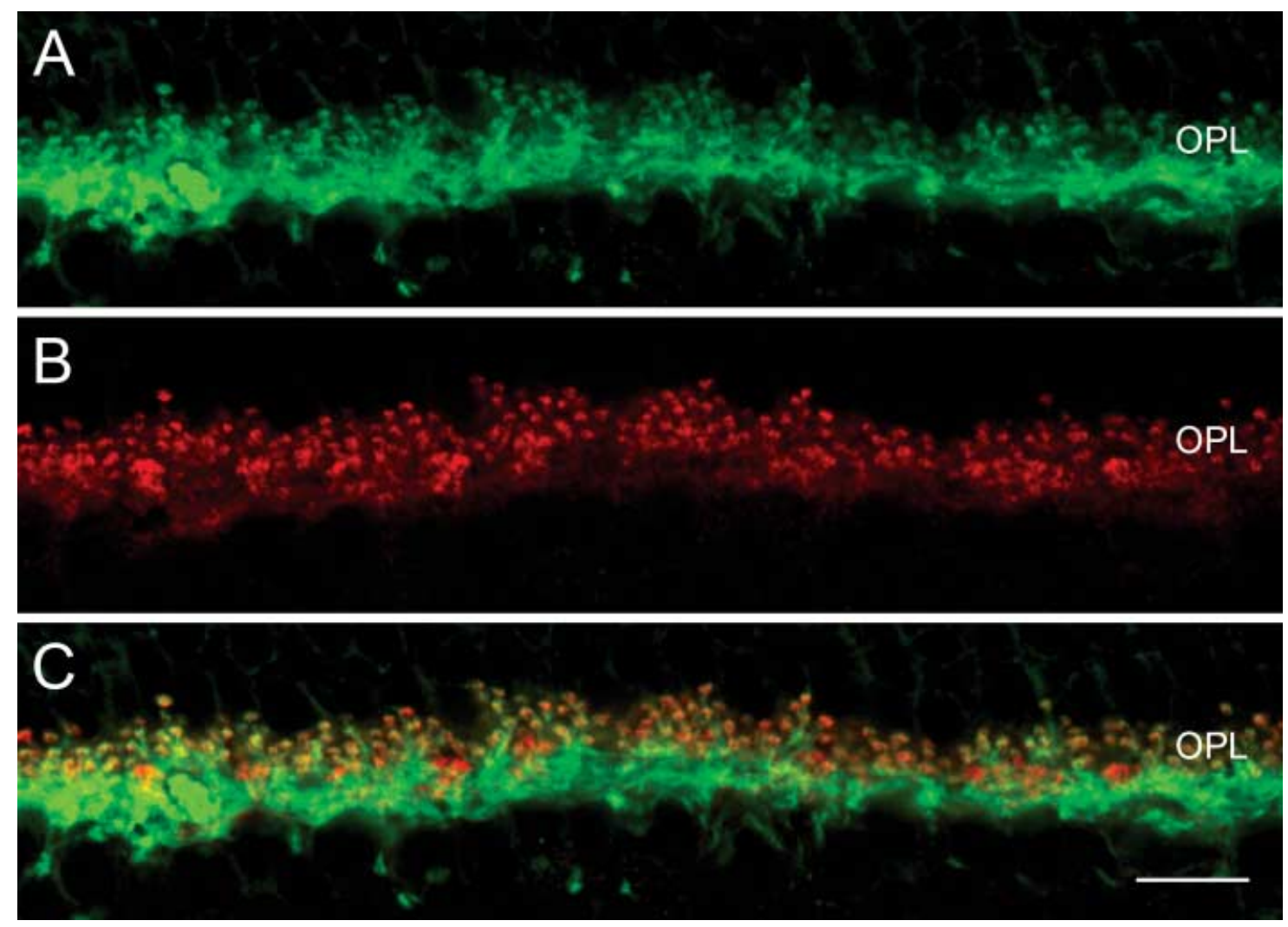

Fig. 7. Syntaxin-4 and SNAP-25 co-localize in horizontal cell processes and endings. Vertical sections of mouse outer retina double labeled for (A) SNAP-25 (green) and (B) syntaxin-4 (red). (C) The merged image shows colocalization of the SNARE proteins in horizontal cell processes and tips. (A to C) Projection of 3 images. OPL, outer plexiform layer. Scale bar, $10 \mu \mathrm{m}$ (A to C in C).

process more like regulated secretion rather than conventional vesicular neurotransmitter exocytosis.

A non-transmitter release role for syntaxin-4 in horizontal cells remains a possibility. For example, syntaxin- 4 may participate in the regulated delivery of postsynaptic AMPA receptors (Nicoll et al., 2006) to the plasma membranes of horizontal cell processes and tips (Morigiwa \& Vardi, 1999; Qin \& Pourcho, 1999a, 1999b; Hack et al., 2001; Haverkamp et al., 2000; Pan \& Massey, 2007), although such synaptic plasticity has not been demonstrated for mammalian horizontal cells. Rapid AMPA receptor cycling, however, has been reported to occur in dendrites of ON ganglion cells in the rodent retina (Xia et al., 2006).

\section{Other roles for syntaxins in neurotransmission}

Syntaxin-1a (Hirano et al., 2005a) and syntaxin-4 (this report) have been localized to horizontal cell processes, with much stronger expression of syntaxin-4 than syntaxin-1a. A role in vesicular release could utilize either or both syntaxin isoforms, because both target vesicles to the plasma membrane. A possibility is that the different isoforms impart different kinetics to the exocytosis, or perhaps that there is heterogeneity between the vesicles and their contents. Besides its established role in synaptic vesicle exocytosis (Wang \& Tang, 2006), syntaxin-1a has been implicated in synaptic plasticity in central neurons (Fujiwara et al., 2006). SNARE proteins are known to modulate the activities of N- and P/Q-type calcium channels (Jarvis \& Zamponi, 2005; Keith et al., 2007) and other ion channels (Quick, 2006) and to regulate a variety of plasma membrane transporters for neurotransmitters (e.g., GABA transporter-1, norepinephrine transporter, glycine transporter-1/-2, glutamate transporter EAAT3; González \& Robinson, 2004; Quick, 2006). Regulation of these transporters includes influencing transporter surface availability, turnover at the plasma membrane, and coupling to intracellular signaling pathways, as well as affecting their intrinsic transport activity (González \& Robinson, 2004; Quick, 2006).

\section{Site of transmitter action}

The majority of the syntaxin- 4 immunoreactivity is concentrated at the horizontal endings at rod and cone terminals, suggesting that it participates in horizontal cell communication with its postsynaptic partners, the photoreceptors and bipolar cells, and possibly in an autocrine fashion onto horizontal cells (Koulen et al., 1998; Feigenspan \& Weiler, 2004; Varela et al., 2005). The current assumption is that the synaptic interactions are taking place in and around the triad synapse in the outer plexiform layer; although, the input and output sites remain undefined morphologically. The localization of various synaptic proteins (e.g., syntaxin-1a, synapsin I and complexin-I/II) to horizontal cell processes and tips at both rod and cone terminals, suggests that exocytosis could occur from both axons and dendrites of horizontal cells. The identification of the specific roles of these proteins in vesicular release will require biochemical and physiological techniques to confirm and extend the immunocytochemical localizations. 
Horizontal cell processes and endings may be sites of secretion or vesicular release, analogous to calcium-dependent somatodendritic release of dopamine (DA) or serotonin from mesencephalic neurons (Bustos et al., 2004; De-Miguel \& Trueta, 2005). Recently, Fortin et al. (2006) put forth evidence that SNARE proteins are necessary for basal, spontaneous somatodendritic DA release from midbrain dopaminergic neurons. There are a number of similarities between the somatodendritic release of DA from substantia nigra neurons and the putative exocytotic release of transmitter from horizontal cells. In both systems, clear-cut postsynaptic sites are rare (Pickel et al., 1996), and there are few vesicles in the somata and dendrites (Nirenberg et al., 1996a). DA receptors are largely extrasynaptic (Cragg \& Rice, 2004). GABA receptors are found along the shafts of bipolar cell dendrites, largely outside of the photoreceptor terminals (Greferath et al., 1994; Enz et al., 1996; Haverkamp et al., 2000) between two layers of horizontal cell processes in primate retina (Haverkamp et al., 2000). In cat retina, $\mathrm{GABA}_{\mathrm{A}}$ receptors were localized to the basal processes of cones, which lack structures of conventional chemical synapses (Vardi et al., 1992). Mesencephalic dopaminergic neurons release DA from both the axon terminals and the somatodendritic region (Bustos et al., 2004). Similarly, horizontal cells appear to have many vesicular release proteins in their dendrites and axons, suggesting that exocytosis occurs from both compartments. In mesencephalic neurons, DA is present in the smooth endoplasmic reticulum of dendrites (Björkland \& Lindvall, 1975; Bustos et al., 2004). The dopamine transporter occurs extrasynaptically on saccules of Golgi and tubulovesicular organelles (Nirenberg et al., $1996 b$ ). It remains to be shown that GABA or a related neurotransmitter accumulates in similar structures in the processes of horizontal cells. It is known that DA release is calcium-dependent (Geffen et al., 1976; Chen \& Rice, 2001), although the calcium dependence between somatodendritic and axonal DA release differs (Chen \& Rice, 2001). Further, the somatodendritic release from nigral neurons does not result from reverse transport, but rather is a SNARE protein-dependent process (Fortin et al., 2006). Similarly, in mammalian retinae, horizontal cells do not express plasma membrane GABA transporters (Johnson et al., 1996), that have been described to mediate GABA release from non-mammalian horizontal cells (Schwartz, 2002). Somatodendritic DA release results in volume transmission of the DA signal (Pickel et al., 1996; Cragg \& Rice, 2004). The intriguing similarities between DA release from mesencephalic neurons and transmitter release from horizontal cells suggests that signaling by horizontal cells may occur also by volume transmission.

Receptive field surround formation may be mediated by horizontal cell feedback onto cone terminals or by feed-forward onto bipolar cell dendrites. In mammalian retina, horizontal cell feedback onto cones has been suggested by expression of $\mathrm{GABA}_{\mathrm{A}}$ receptor subunit cDNAs by photoreceptors detected by in situ hybridization immunohistochemistry and single-cell RT-PCR (Greferath et al., 1995; Grigorenko \& Yeh, 1994; Vardi et al., 1998). Cone terminals in cat, pig, mouse and rat retinae show ionotropic GABA receptor immunolabeling (Vardi et al., 1992; Picaud et al., 1998; Pattnaik et al., 2000). In addition, recordings from mouse and pig cones indicate the presence of functional $\mathrm{GABA}_{\mathrm{A}}$ and $\mathrm{GABA}_{\mathrm{C}}$ receptors (Pattnaik et al., 2000); whereas, rods in porcine retina exhibit little sensitivity to GABA (Picaud et al., 1998).

Growing evidence suggests GABA released from horizontal cells may mediate a feed-forward signal onto bipolar cell dendrites to generate antagonistic surround receptive fields (Peichl et al.,
1998; Yang, 2004). Receptive field surrounds have been described for primate bipolar cells (Dacey et al., 2000). Ionotropic GABA receptors localize to bipolar cell dendrites (Greferath et al., 1994; Enz et al., 1996; Vardi \& Sterling, 1994), and GABA evokes chloride currents in dendrites of mouse bipolar cells (Suzuki et al., 1990). In the monkey retina, $\mathrm{GABA}_{\mathrm{A}} \mathrm{Rs}$ are found clustered on bipolar cell dendrites between two layers of horizontal cell processes at cone pedicles (Haverkamp et al., 2000). There is a differential distribution of chloride transporters in bipolar cell processes that likely set up a chloride gradient between the dendrites and axon terminals ( $\mathrm{Vu}$ et al., 2000; Vardi et al., 2000), providing a mechanism for generating surround responses of different polarities. Indeed, there is evidence that differential chloride gradients are established in different bipolar cell types (Satoh et al., 2001; Varela et al., 2005; Duebel et al., 2006). Recently, elegant work from Euler's group (Duebel et al., 2006) indicates that somatodendritic chloride gradients in ON bipolar cells are present and sufficient to generate responses to GABA of the correct polarity (i.e., depolarizations in $\mathrm{ON}$ bipolar cell dendrites), which maintain high intracellular chloride concentrations.

In summary, we report strong expression of syntaxin-4 and SNAP-25 in the processes and endings of mammalian horizontal cells at both rod and cone terminals. This addition to the panoply of vesicular release proteins localized previously to horizontal cell processes (Hirano et al., 2005a) suggests that the molecular machinery of exocytosis is present in these cells.

\section{Acknowledgments}

The authors gratefully acknowledge the excellent technical assistance with the EM by Hanna Regus-Leidig, Dana Specht, and Gong-Sun Nam (MPIH) and technical support of Uyen-chi Huynh and John Lee (UCLA). The authors also thank Drs. Salvatore L. Stella, Jr., Michaela Bitzer, and Iona D. Raymond for a critical reading and improving the manuscript, and helpful discussions during the course of the work. The work was supported by NIH EY 15573, VA Merit Review and Senior Career Scientist Award, and UCLA Stein-Oppenheimer Award (NCB).

\section{References}

Bennett, M.K., García-Arraras, J.E., Elferink, L.A., Peterson, K., Fleming, A.M., Hazuka, C.D. \& Scheller, R.H. (1993). The syntaxin family of vesicular transport receptors. Cell 74, 863-873.

BJörkland, A. \& Lindvall, O. (1975). Dopamine in dendrites of substantia nigra neurons: Suggestion for a role in dendritic terminals. Brain Research 83, 531-537.

Blank, U., Cyprien, B., Martin-Verdeaux, S., Paumet, F., Pombo, I., Rivera, J., Roa, M. \& Varin-Blank, N. (2001). SNARES and associated regulators in the control of exocytosis in the RBL-2H3 mast cell line. Molecular Immunology 38, 1341-1345.

Blanks, J.C. \& Johnson, L.V. (1984). Specific binding of peanut lectin to a class of retinal photoreceptor cells. A species comparison. Investigative Ophthalmology \& Visual Science 25, 546-557.

Brandstätter, J.H., Dick, O. \& Boeckers, T.M. (2004). The postsynaptic scaffold proteins ProSAP1/Shank2 and Homer 1 are associated with glutamate receptor complexes at rat retinal synapses. The Journal of Comparative Neurology 475, 551-563.

Bustos, G., Abarca, K., Campusano, J., Bustos, V., Noriega, V. \& AliagA, E. (2004). Functional interactions between somatodendritic dopamine release, glutamate receptors and brain-derived neurotrophic factor expression in mesencephalic structures of the brain. Brain Research Reviews 47, 126-144.

Chen, B.T. \& Rice, M.E. (2001). Novel $\mathrm{Ca}^{2+}$ dependence and time course of somatodendritic dopamine release: Substantia nigra versus striatum. The Journal of Neuroscience 21, 7841-7847.

Chen, D., Lemons, P.P., Schraw, T. \& Whiteheart, S.W. (2000). Molecular mechanisms of platelet exocytosis: Role of SNAP-23 and syntaxin 2 and 4 in lysosome release. Blood 96, 1782-1788. 
CHEN, Y.A. \& Scheller, R.H. (2001). SNARE-mediated membrane fusion. Nature Reviews. Molecular Cell Biology 2, 98-106.

CRAGG, S.J. \& RICE, M.E. (2004). Dancing past the DAT at a DA synapse. Trends in Neurosciences 27, 270-277.

Cueva, J.G., Haverkamp, S., Reimer, R.J., Edwards, R., Wässle, H. \& BRECHA, N.C. (2002). Vesicular gamma-aminobutyric acid transporter expression in amacrine and horizontal cells. The Journal of Comparative Neurology 445, 227-237.

Dacey, D., Packer, O.S., Diller, L., Brainard, D., Peterson, B. \& Lee, B. (2000). Center surround receptive field structure of cone bipolar cells in primate retina. Vision Research 40, 1801-1811.

De-Miguel, F.F. \& Trueta, C. (2005). Synaptic and extrasynaptic secretion of serotonin. Cellular and Molecular Neurobiology 25, 297-312.

Dowling, J.E. \& BoycotT, B.B. (1966). Organization of the primate retina: Electron microscopy. Proceedings of the Royal Society of London Series B Biological Sciences 166, 80-111.

Dowling, J.E., Brown, J.E. \& MAJor, D. (1966). Synapses of horizontal cells in rabbit and cat retinas. Science 153, 1639-1641.

Duebel, J., Haverkamp, S., Schleich, W., Feng, G., Augustine, G.J., Kuner, T. \& Euler, T. (2006). Two-photon imaging reveals somatodendritic chloride gradient in retinal ON-type bipolar cells expressing the biosensor Clomeleon. Neuron 49, 81-94.

Enz, R., Brandstätter, J.H., Wëssle, H. \& Bormann, J. (1996). Immunocytochemical localization of GABAc receptor rho subunits in the mammalian retina. The Journal of Comparative Neurology 16, 4479-4490.

Feigenspan, A. \& WeILeR, R. (2004). Electrophysiological properties of mouse horizontal cell $\mathrm{GABA}_{\mathrm{A}}$ receptors. Journal of Neurophysiology 92, 2789-2801.

Fortin, G.D., Desrosiers, C.C., Yamaguchi, N. \& Trudeau, L.E. (2006). Basal somatodendritic dopamine release requires snare proteins. Journal of Neurochemistry 96, 1740-1749.

Fournier, K.M. \& Robinson, M.B. (2006). A dominant-negative variant of SNAP-23 decreases the cell surface expression of the neuronal glutamate transporter EAAC1 by slowing constitutive delivery. Neurochemistry International 48, 596-603.

Fujiwara, T., Mishima, T., Kofuji, T., Chiba, T., Tanaka, K., Yamamoto, A. \& Akagawa, K. (2006). Analysis of knock-out mice to determine the role of HPC-1/syntaxin 1A in expressing synaptic plasticity. The Journal of Neuroscience 26, 5767-5776.

FyK-Kolodziej, B., Dzhagaryan, A., Qin, P. \& Pourcho, R.G. (2004). Immunocytochemical localization of three vesicular glutamate transporters in the cat retina. The Journal of Comparative Neurology 475, $518-530$.

Geffen, L.B., Jessell, T.M., Cuello, A.C. \& Iversen, L.L. (1976). Nigral and striatal dopamine release under sensory stimuli. Nature 269, $340-342$.

GonzÁlez, M.I. \& Robinson, M.B. (2004). Neurotransmitter transporters: Why dance with so many partners? Current Opinion in Pharmacology 4, 30-35.

Gouraud, S., laera, A., Calamita, G., Carmosino, M., Procino, G., Rossetto, O., Mannucci, R., Rosenthal, W., Svelto, M. \& ValENTI, G. (2002). Functional involvement of VAMP/synaptobrevin-2 in cAMP-stimulated aquaporin-2 translocation in renal collecting duct cells. Journal of Cell Science 115, 3667-3674.

Greferath, U., Grünert, U., Fritschy, J.M., Stephenson, A., Möhler, H. \& Wässle, H. (1995). GABA A $_{\mathrm{A}}$ receptor subunits have differential distributions in the rat retina: In situ hybridization and immunohistochemistry. The Journal of Comparative Neurology 353, 553-571.

Greferath, U., Grünert, U., Müller, F. \& Wässle, H. (1994). Localization of GABAA receptors in the rabbit retina. Cell and Tissue Research 276, 295-307.

Greferath, U., GRÜNERT, U. \& Wässle, H. (1990). Rod bipolar cells in the mammalian retina show protein kinase $\mathrm{C}$-like immunoreactivity. The Journal of Comparative Neurology 301, 433-442.

GrigorenKo, E.V. \& YeH, H.H. (1994). Expression profiling of GABAA receptor beta-subunits in the rat retina. Visual Neuroscience 11, 279-387.

GRÜNERT, U. \& WÄSSLE, H. (1993). Immunocytochemical localization of glycine receptors in the mammalian retina. The Journal of Comparative Neurology 335, 523-537.

Grusovin, J. \& Macaulay, S.L. (2003). Snares for GLUT4-mechanisms directing vesicular trafficking of GLUT4. Frontiers in Bioscience 8, d620-641.

Hack, I., Frech, M., Dick, O., Peichl, L. \& Brandstätter, J.H. (2001). Heterogeneous distribution of AMPA glutamate receptor subunits at the photoreceptor synapses of rodent retina. European Journal of Neuroscience 13, 15-24.

Hack, I., Peichl, L. \& Brandstätter, J.H. (1999). An alternative pathway for rod signals in the rodent retina: rod photoreceptors, cone bipolar cells, and the localization of glutamate receptors. Proceedings of the National Academy of Sciences of the United States of America 96, 14130-14135.

Hansen, N.J., Antonin, W. \& Edwardson, J.M. (1999). Identification of SNAREs involved in regulated exocytosis in the pancreatic acinar cell. The Journal of Biological Chemistry 274, 22871-22876.

Haverkamp, S., Grünert, U. \& Wässle, H. (2000). The cone pedicle, a complex synapse. Neuron 27, 85-95.

HaverKamp, S. \& Wässle, H. (2000). Immunocytochemical analysis of the mouse retina. The Journal of Comparative Neurology 424, $1-23$.

Hirano, A.A., Brandstätter, J.H. \& Brecha, N.C. (2005a). Cellular distribution and subcellular localization of molecular components of vesicular transmitter release in horizontal cells of rabbit retina. The Journal of Comparative Neurology 488, 70-81.

Hirano, A.A., Brandstätter, J.H., Morgans, C.W. \& Brecha, N.C. $(2005 b)$. SNAP-25 expression in mammalian horizontal cells. Program No. 741.1. 2005 Abstract Viewer/Itinerary Planner. Washington, DC: Society for Neuroscience, 2005. Online.

Hirano, A.A., Vila, A. \& Brecha, N.C. (2006). Syntaxin-4 expression in mammalian horizontal cells. Investigative Ophthalmology \& Visual Science 47, E-Abstract 391

JAHN, R. \& SchelleR, R.H. (2006). SNAREs-engines for membrane fusion. Nature Reviews. Molecular Cell Biology 7, 631-643.

JARVIS, S.E. \& ZAMPONI, G.W. (2005). Masters or slaves? Vesicle release machinery and the regulation of presynaptic calcium channels. Cell Calcium 37, 483-488.

Jellali, A., Stussi-Garaud, C., Gasnier, B., Rendon, A., Sahel, J.A., Dreyfus, H. \& PICAUd, S. (2002). Cellular localization of the vesicular inhibitory amino acid transporter in the mouse and human retina. The Journal of Comparative Neurology 449, 76-87.

Johnson, J., Chen, T.K., Rickman, D.W., Evans, C. \& Brecha, N.C. (1996). Multiple gamma-aminobutyric acid plasma membrane transporters (GAT-1, GAT-2, GAT-3) in the rat retina. The Journal of Comparative Neurology 375, 212-224.

Johnson, J., Tian, N., Caywood, M.S., Reimer, R.J., Edwards, R.H. \& Copenhagen, D.R. (2003). Vesicular neurotransmitter transporter expression in developing postnatal rodent retina: GABA and glycine precede glutamate. The Journal of Neuroscience 23, 518-529.

Keith, R.K., Poage, R.E., Yokoyama, C.T., Catterall, W.A. \& MeRINEY, S.D. (2007). Bidirectional modulation of transmitter release by calcium channel/syntaxin interactions in vivo. The Journal of Neuroscience 27, 265-269.

Koulen, P., Malitschek, B., Kuhn, R., Bettler, B., Wässle, H. \& Brandstätter, J.H. (1998). Presynaptic and postsynaptic localization of $\mathrm{GABA}_{\mathrm{B}}$ receptors in neurons of the rat retina. European Journal of Neuroscience 10, 1446-1456.

Lemons, P.P., Chen, D. \& Whiteheart, S.W. (2000). Molecular mechanisms of platelet exocytosis: Requirements for alpha-granule release. Biochemical and Biophysical Research Communications 267, 875-880.

LiNBERG, K.A. \& FisHER, S.K. (1988). Ultrastructural evidence that horizontal cell axon terminals are presynaptic in the human retina. The Journal of Comparative Neurology 268, 281-297.

Logan, M.R., Odemuyiwa, S.O. \& Moqbel, R. (2003). Understanding exocytosis in immune and inflammatory cells: The molecular basis of mediator secretion. The Journal of Allergy and Clinical Immunology 111, 923-932.

Madison, D.L., Krueger, W.H., Cheng, D., Trapp, B.D. \& Pfeiffer, S.E. (1999). SNARE complex proteins, including the cognate pair VAMP-2 and syntaxin-4, are expressed in cultured oligodendrocytes Journal of Neurochemistry 72, 988-998.

Massey, S.C. \& Mills, S.L. (1996). A calbindin-immunoreactive cone bipolar cell type in the rabbit retina. The Journal of Comparative Neurology 366, 15-33.

MorigiWA, K. \& VARDI, N. (1999). Differential expression of ionotropic glutamate receptor subunits in the outer retina. The Journal of Comparative Neurology 405, 173-184.

Negishi, K., Sato, S. \& Teranishi, T. (1988). Dopamine cells and rod bipolar cells contain protein kinase C-like immunoreactivity in some vertebrate retinas. Neuroscience Letters 94, 247-252. 
Nicoll, R.A., Tomita, S. \& BREdT, D.S. (2006). Auxiliary subunits assist AMPA-type glutamate receptors. Science 311, 1253-1256.

Nirenberg, M.J., Chan, J., Liu, Y., Edwards, R.H. \& Pickel, V.M. (1996a). Ultrastructural localization of the vesicular monoamine transporter-2 in midbrain dopaminergic neurons: Potential sites for somatodendritic storage and release of dopamine. The Journal of Neuroscience 16, 4135-4145.

Nirenberg, M.J., Vaughan, R.A., Uhl, G.R., Kuhar, M.J. \& Pickel, V.M. (1996b). The dopamine transporter is localized to dendritic and axonal plasma membranes of nigrostriatal dopaminergic neurons. The Journal of Neuroscience 16, 437-447.

NoDA, Y. \& SASAKI, S. (2005). Trafficking mechanisms of water channel aquaporin-2. Biology of the Cell 97, 885-892.

Olson, A.L., Knight, J.B. \& Pessin, J.E. (1997). Syntaxin 4, VAMP2, and/or VAMP3/cellubrevin are functional target membrane and vesicle SNAP receptors for insulin-stimulated GLUT4 translocation in adipocytes. Molecular and Cellular Biology 17, 2425-2435.

Pagan, J.K., Wylie, F.G., Joseph, S., Widberg, C., Bryant, N.J., James, D.E. \& STOw, J.L. (2003). The t-SNARE syntaxin 4 is regulated during macrophage activation to function in membrane traffic and cytokine secretion. Current Biology 13, 156-160.

PAN, F. \& MASSEY, S.C. (2007). Rod and cone input to horizontal cells in the rabbit retina. The Journal of Comparative Neurology 500, 815-831.

Pattnaik, B., Jellali, A., Sahel, J., Dreyfus, H. \& Picaud, S. (2000). $\mathrm{GABA}_{\mathrm{C}}$ receptors are localized with microtubule-associated protein $1 \mathrm{~B}$ in mammalian cone photoreceptors. The Journal of Neuroscience $\mathbf{2 0}$, 6789-6796.

Peichl, L., Sandmann, D. \& Boycott, B.B. (1998). Comparative anatomy and function of mammalian horizontal cells. In Development and Organization of the Retina, eds. Chalupa L.M. \& Finlay B.L., pp. 147172. New York: Plenum Press.

Peichl, L. \& González-Soriano, J. (1994). Morphological types of horizontal cell in rodent retinae: A comparison of rat, mouse, gerbil, and guinea pig. Visual Neuroscience 11, 501-517.

Peters, A., Palay, S.L. \& Webster, H. DeF. (1991). The Fine Structure of the Nervous System. Neurons and their Supporting Cells Third Edition. New York: Oxford University Press.

Piatigorsky, J. (2001). Dual use of the transcriptional repressor (CtBP2)/ ribbon synapse (RIBEYE) gene: How prevalent are multifunctional genes? Trends in Neurosciences 24, 555-557.

Picaud, S., Pattnaik, B., Hicks, D., Forster, V., Fontaine, V., Sahel, J. \& Dreyfus, H. (1998). GABAA and GABAC receptors in adult porcine cones: Evidence from a photoreceptor-glia co-culture model. Journal of Physiology 513, 33-42.

Pickel, V.M., Nirenberg, M.J. \& Milner, T.A. (1996). Ultrastructural view of central catecholaminergic transmission: Immunocytochemical localization of synthesizing enzymes, transporters and reporters. Journal of Neurocytology 25, 843-856.

Qin, P. \& Pourcho, R.G. (1999a). Localization of AMPA-selective glutamate receptor subunits in the cat retina: A light- and electronmicroscopic study. Visual Neuroscience 16, 169-77.

QIN, P. \& Pourcho, R.G. (1999b). AMPA-selective glutamate receptor subunits GluR2 and GluR4 in the cat retina: An immunocytochemical study. Visual Neuroscience 16, 1105-1114.

QUICK, M.W. (2006). The role of SNARE proteins in trafficking and function of neurotransmitter transporters. Handbook of Experimental Pharmacology 175, 181-196.

Rivera, L., Blanco, R. \& de la Villa, P. (2001). Calcium-permeable glutamate receptors in horizontal cells of the mammalian retina. Visual Neuroscience 18, 995-1002.

RIzo, J. \& SÜDHOF, T.C. (2002). SNAREs and Munc 18 in synaptic vesicle fusion. Nature Reviews. Neuroscience 3, 641-653.

RoBinson, M.B. (2006). Acute regulation of sodium-dependent glutamate transporters: A focus on constitutive and regulated trafficking. Handbook of Experimental Pharmacology 175, 252-275.

RöHrenbeck, J., Wässle, H. \& Heizmann, C.W. (1987). Immunocytochemical labelling of horizontal cells in mammalian retina using antibodies against calcium-binding proteins. Neuroscience Letters 77, 255-260.

Salaün, C., James, D.J., Greaves, J. \& Chamberlain, L.H. (2004). Plasma membrane targeting of exocytic SNARE proteins. Biochimica et Biophysica Acta 1693, 81-89.

SassoÉ-Pognetto, M., WÄssle, H. \& Grünert, U. (1994). Glycinergic synapses in the rod pathway of the rat retina: cone bipolar cells express the $\alpha 1$ subunit of the glycine receptor. The Journal of Neuroscience $\mathbf{1 4}$ 5131-5146.

Satoh, H., Kaneda, M. \& Kaneko, A. (2001). Intracellular chloride concentration is higher in rod bipolar cells than in cone bipolar cells of the mouse retina. Neuroscience Letters 310, 161-164.

Schmitz, F., Konigstorfer, A. \& SüDhof, T.C. (2000). RIBEYE, a component of synaptic ribbons: a protein's journey through evolution provides insight into synaptic ribbon function. Neuron 28, 857-872.

Schubert, T., Weiler, R. \& FeigensPan, A. (2006). Intracellular calcium is regulated by different pathways in horizontal cells of the mouse retina. Journal of Neurophysiology 96, 1278-1292.

Schwartz, E.A. (2002). Transport-mediated synapses in the retina. Physiological Reviews 82, 875-891.

Sherry, D.M., Mitchell, R., Standifer, K.M. \& Du Plessis, B. (2006). Distribution of plasma membrane-associated syntaxins 1 through 4 indicates distinct trafficking functions in the synaptic layers of the mouse retina. BioMed Central Neuroscience 7, 54.

Sherry, D.M., Wang, M.M., Bates, J. \& Frishman, L.J. (2003). Expression of vesicular glutamate transporter 1 in the mouse retina reveals temporal ordering in development of rod vs. cone and ON vs. OFF circuits. The Journal of Comparative Neurology 465, 480-498.

Spiwoks-Becker, I., Vollrath, L., Seeliger, M.W., Jaissle, G., EshKIND, L.G. \& Leube, R.E. (2001). Synaptic vesicle alterations in rod photoreceptors of synaptophysin-deficient mice. Neuroscience 107, $127-142$.

Spurlin, B.A., Park, S.Y., Nevins, A.K., Kim, J.K. \& Thurmond, D.C. (2004). Syntaxin 4 transgenic mice exhibit enhanced insulin-mediated glucose uptake in skeletal muscle. Diabetes 53, 2223-2231.

Spurlin, B.A. \& Thurmond, D.C. (2006). Syntaxin 4 facilitates biphasic glucose-stimulated insulin secretion from pancreatic beta-cells. Molecular Endocrinology 20, 183-193.

Stow, J.L., Manderson, A.P. \& Murray, R.Z. (2006). SNAREing immunity: The role of SNAREs in the immune system. Nature Reviews. Immunology 6, 919-929.

SüDHOF, T.C. (2004). The synaptic vesicle cycle. Annual Review of Neuroscience 27, 509-547.

Suzuki, S., Tachibana, M. \& Kaneko, A. (1990). Effects of glycine and GABA on isolated bipolar cells of the mouse retina. Journal of Physiology 421, 645-662.

Teng, F.Y.H., WAng, Y. \& TANG, B.L. (2001). The syntaxins. Genome Biology 2, 3012.1-3012.7.

ter Beest, M.B., Chapin, S.J., Avrahami, D. \& Mostov, K.E. (2005). The role of syntaxins in the specificity of vesicle targeting in polarized epithelial cells. Molecular Biology of the Cell 16, 5784-5792.

Todd, A.J., Hughes, D.I., Polgár, E., Nagy, G.G., Mackie, M., OtTERSEN, O.P. \& MAXwell, D.J. (2003). The expression of vesicular glutamate transporters VGLUT1 and VGLUT2 in neurochemically defined axonal populations in the rat spinal cord with emphasis on the dorsal horn. European Journal of Neuroscience 17, 13-27.

tom Dieck, S., Altrock, W.D., Kessels, M.M., Qualmann, B., Regus, H., Brauner, D., Fejtova, A., Bracko, O., Gundelfinger, E.D. \& BrandSTÄTtER, J.H. (2005). Molecular dissection of the photoreceptor ribbon synapse: Physical interaction of Bassoon and RIBEYE is essential for the assembly of the ribbon complex. The Journal of Cell Biology 168, 825-836.

tom DiecK, S. \& BRandstätter, J.H. (2006). Ribbon synapses of the retina. Cell and Tissue Research 326, 339-346.

Vardi, N., Masarachia, P. \& Sterling, P. (1992). Immunoreactivity to GABAA receptor in the outer plexiform layer of the cat retina. The Journal of Comparative Neurology 320, 394-397.

Vardi, N., Morigiwa, K., Want, T.L., Shi, Y.J. \& Sterling, P. (1998). Neurochemistry of the mammalian cone 'synaptic complex'. Vision Research 38, 1359-1369.

VARdi, N. \& Sterling, P. (1994). Subcellular localization of GABAA receptor on bipolar cells in macaque and human retina. Vision Research 34, 1235-46.

Vardi, N., Zhang, L.L., Payne, J.A. \& Sterling, P. (2000). Evidence that different cation chloride cotransporters in retinal neurons allow opposite responses to GABA. The Journal of Neuroscience 20, 7657-7663.

Varela, C., Blanco, R. \& De la Villa, P. (2005). Depolarizing effect of GABA in rod bipolar cells of the mouse retina. Vision Research $\mathbf{4 5}$, 2659-2667.

Vu, T.Q., Payne, J.A. \& Copenhagen, D.R. (2000). Localization and developmental expression patterns of the neuronal $\mathrm{K}-\mathrm{Cl}$ cotranspor- 
ter $(\mathrm{KCC} 2)$ in the rat retina. The Journal of Neuroscience 20, $1414-1423$.

WANG, Y. \& TANG, B.L. (2006). SNAREs in neurons-beyond synaptic vesicle exocytosis. Molecular Membrane Biology 23, 377-384.

Wässle, H., Koulen, P., Brandstätter, J.H., Fletcher, E.L. \& Becker, C.M. (1998). Glycine and GABA receptors in the mammalian retina. Vision Research 38, 1411-1430.
Xia, Y., Carroll, R.C. \& Nawy, S. (2006). State-dependent AMPA receptor trafficking in the mammalian retina. The Journal of Neuroscience 26, 5028-5036.

YANG, X.L. (2004). Characterization of receptors for glutamate and GABA in retinal neurons. Progress in Neurobiology 73, 127-150. 